\title{
Two Cases of Immunoglobulin G4-Related Sclerosing Disease Mimicking Nasopharyngeal Carcinoma
}

\author{
Hyung Joon Yoon, Woo Sung Park, Yong Bae Ji, and Seung Hwan Lee \\ Department of Otolaryngology-Head and Neck Surgery, College of Medicine, Hanyang University, Seoul, Korea
}

비인두암으로 오인된 Immunoglobulin G4 연관 경화성 질환 2예

윤형준 · 박우성 · 지용배 · 이승환

한양대학교 의과대학 이비인후-두경부외과학교실

\author{
Received June 8, 2015 \\ Revised July 4,2015 \\ Accepted July 6, 2015 \\ Address for correspondence \\ Yong Bae Ji, MD \\ Department of Otolaryngology- \\ Head and Neck Surgery, \\ College of Medicine, \\ Hanyang University, \\ 222-1 Wangsimni-ro, Seongdong-gu, \\ Seoul 04763, Korea \\ Tel $+82-2-2290-8585$ \\ Fax $+82-2-2293-3335$ \\ E-mail jyb20000@hanyang.ac.kr
}

Immunoglobulin G4 (IgG4)-related sclerosing disease is characterized by a systemic involvement of tumor-like lesions with IgG4-positive plasma cell. This disease can occur in the salivary, lacrimal and pituitary gland in the head and neck region. The involvement of IgG4-related sclerosing disease at nasopharynx is extremely rare, so it is hard to make an accurate diagnosis. Recently, we have experienced two cases of IgG4-related sclerosing disease arising from the nasopharynx. Diffusely enhancing mass with surrounding bony erosion and increased 18-F fludeoxyglucose uptake was found at the nasopharynx, suggesting malignancy. But the cases were finally confirmed as IgG4-related sclerosig disease by punch biopsy and the symtoms improved with glucocorticoid therapy. We report our experiences with a literature review. Korean J Otorhinolaryngol-Head Neck Surg 2016;59(4):304-8

Key Words Autoimmune $\cdot$ Immunoglobulin G $\cdot$ Nasopharynx $\cdot$ Sclerosing disease.

\section{서 론}

Immunoglobulin G4(IgG4) 연관 경화성 질환(IgG4 related sclerosing disease)은 면역조직화학 검사상 $\mathrm{IgG} 4$ 에 양성을 보이며, 전신에 종물과 유사한 양상의 침범을 보이는 특징을 갖고 있는 질환으로 비교적 최근에 임상병리학적으로 분류 된 질환이다. ${ }^{1)} \mathrm{IgG} 4$ 연관 경화성 질환은 자가면역성 췌장염 을 연구하는 과정에서 처음 알려졌으며, ${ }^{2}$ 이후 담관에서 경화 성 담관염(sclerosing cholangitis), ${ }^{3)}$ 간에서 염증성 위종양(inflammatory pseudotumor), 후복막강에서 후복막섬유증식 증(retroperitoneal fibrosis), 폐에서 염증성 위종양(inflammatory pseudotumor) 및 간질폐렴(interstitial pneumonia) $)^{5)}$ 으로 나타나는 증례들이 보고되었다. 두경부 영역에서 $\mathrm{IgG} 4$ 연관 경화성 질환은 악하선(Küttner tumor), 눈물샘 및 이하 선(Mikulicz's disease), 뇌하수체(lymphoplasmacytic hypophysitis)에 주로 나타나는 것으로 알려져 있으며, ${ }^{6-8)}$ 비강
이나 인후두에도 발생할 수 있으나 그 빈도는 매우 드물다. ${ }^{9}$ 따라서 비인두 부위에 발생한 종물에서 $\mathrm{IgG} 4$ 연관 경화성 질환을 의심하고 진단하기는 쉽지 않은 일이며, 비인두암이 나 뇌기저부 골수염 등과 혼동되기 쉽다. 최근 저자들은 비 인두에 발생하여 비인두암으로 오인되었으나, 결국 $\mathrm{IgG} 4$ 연 관 경화성 질환으로 진단된 2예를 치험하였기에 문헌고찰과 함께 보고하는 바이다.

\section{증 례}

\section{증 례 1}

78세 남자 환자가 내원 2개월 전부터 발생한 우측 측두부 와 우측 경부의 통증을 주소로 내원하였다. 신체진찰에서 비 강, 경부 및 인후두에 특이 소견을 보이지 않았고, 양측 고막 의 천공 소견은 있었으나 이루나 발적 등의 소견은 관찰되지 않았다. 이에 삼차신경통 의심하에 3 주간 보존적 치료를 시 
행하였으나 통증은 호전되지 않고 두통을 동반하였다. 이에 시행한 전산화단층촬영상 우측 비인두 부위에 조영 증가를 보이는 연조직 종물이 관찰되었고, 종물은 부인두 공간 및 반대측으로도 침범하는 양상을 보였으며, 목정맥구멍(jugu-

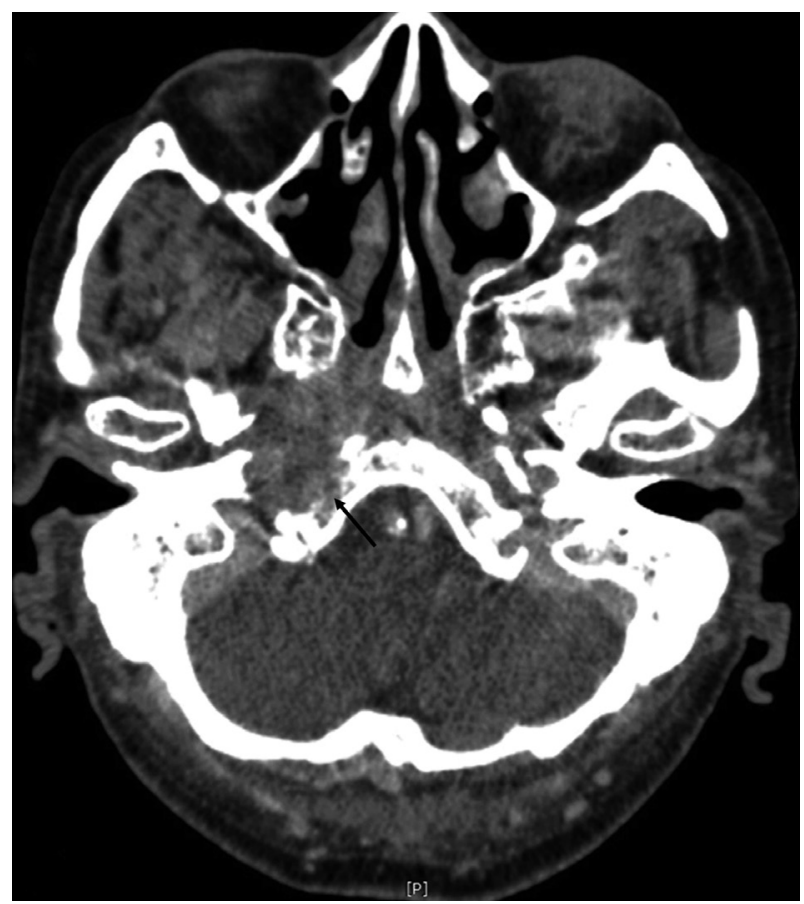

Fig. 1. Axial CT scan showing enhancing soft tissue mass in the right pharyngeal space and erosion in the right skull base around the jugular foramen and right clivus (arrow).

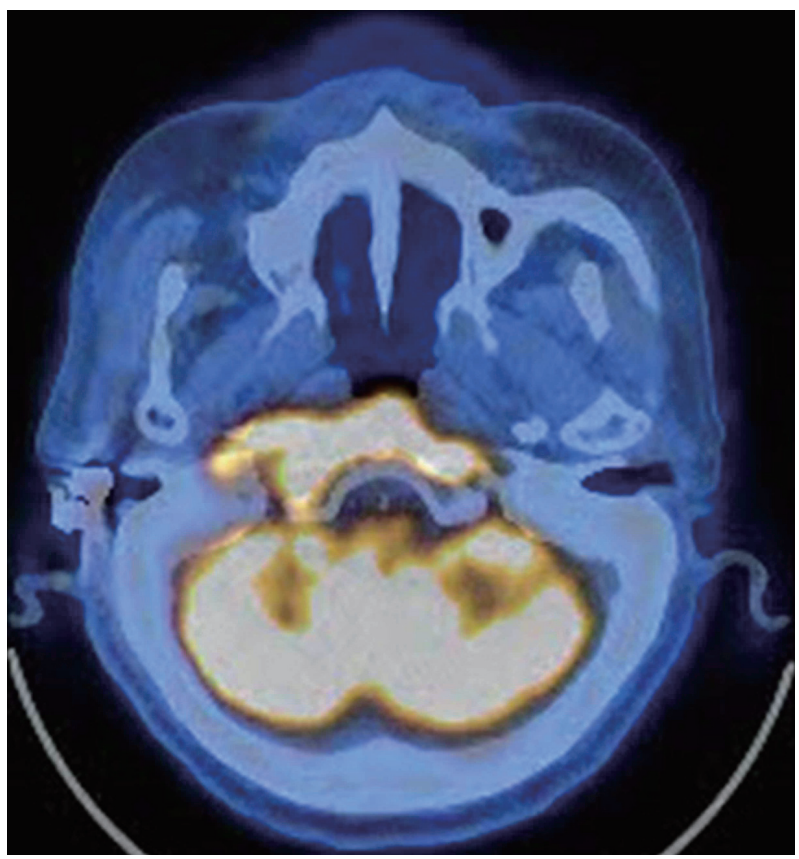

Fig. 2. 18F-fludeoxyglucose positron emission tomography/computed tomography showing hypermetabolic mass at nasopharynx (maxSUV=8.9). lar foramen)주변의 기저부에 미란이 동반되었다(Fig. 1). 양 전자컴퓨터단층촬영에서 비인두의 섭취율이 증가하였다 (maxSUV=8.9)(Fig. 2). 비내시경 검사상 비인두 부위의 점 막에 이상 소견을 보이지 않았으나 전반적으로 팽륜되어 있 었다(Fig. 3). 이에 두개저를 침범한 비인두암의 가능성이 높을 것으로 생각되어 펀치 생검(punch biopsy)을 시행하였으나, 조 직검사 결과 비정형 림프계 세포(atypical lymphoid cells)외 에 특이적인 소견은 관찰되지 않았다. 이에 펀치 생검을 재실 시하였으나 같은 소견만을 보였다. 이에 충분한 깊이에서 충 분한 양의 조직을 얻기 위해 전신마취하에 비인두 점막과 점 막하 조직에서 충분한 양을 채취하여 조직검사를 시행하였 다. 술 중 소견상 점막에는 특이 소견이 관찰되지 않았으며 점막하 조직에서 삼출액이 다소 배출되었으나 종괴는 관찰 되지 않았다. 병리 조직학적 검사상 근육 침윤성 경화(intramuscular infiltrative sclerosis) 및 혈관의 경화증(vascular sclerosis with corresponding luminal narrowing)이 동반된 광범위하고 조밀한 경화 소견이 관찰되었으며, 면역조직화학검 사상 $\mathrm{IgG}$ 및 $\mathrm{IgG} 4$ 에서 양성을 보이는 형질세포(plasma cell) 가 고배율 시야에서 20개 이상 관찰되어 $\mathrm{IgG} 4$ 연관 경화성 질 환으로 진단하였다(Fig. 4). 혈액검사상 $\mathrm{IgG}$ 는 $1040 \mathrm{mg} / \mathrm{dL}$ 로 측정되었으며, 적혈구 침강 속도(erythrocyte sedimentation rate)는 $24 \mathrm{~mm} / \mathrm{hr}, \mathrm{C}$ 반응성 단백질(C-reactive protein)은 $2.03 \mathrm{mg} / \mathrm{dL}$ 로 다소 증가되어 있었다. 이에 고용량 스테로이드 (prednisolone $1 \mathrm{mg} / \mathrm{kg}$ )를 2주간 사용한 후 우측 이통 및 두 통은 호전되었고, 치료 시작 1 개월 후 재촬영한 단층촬영에서

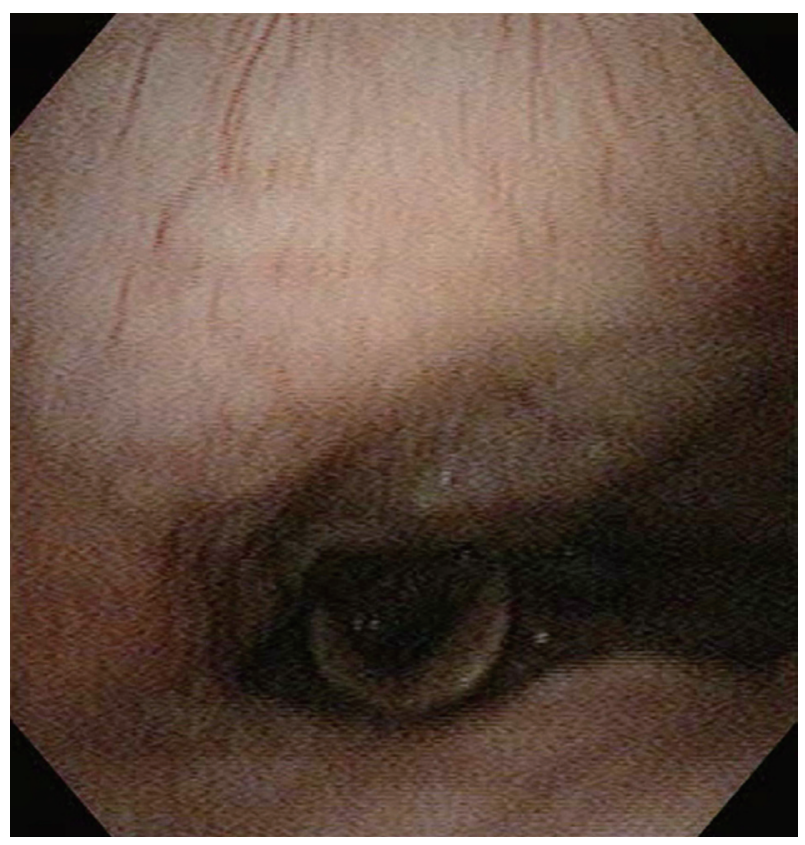

Fig. 3. Laryngofiberscopy of larynx showing bulging of mucosa from right nasopharynx to oropharynx. 

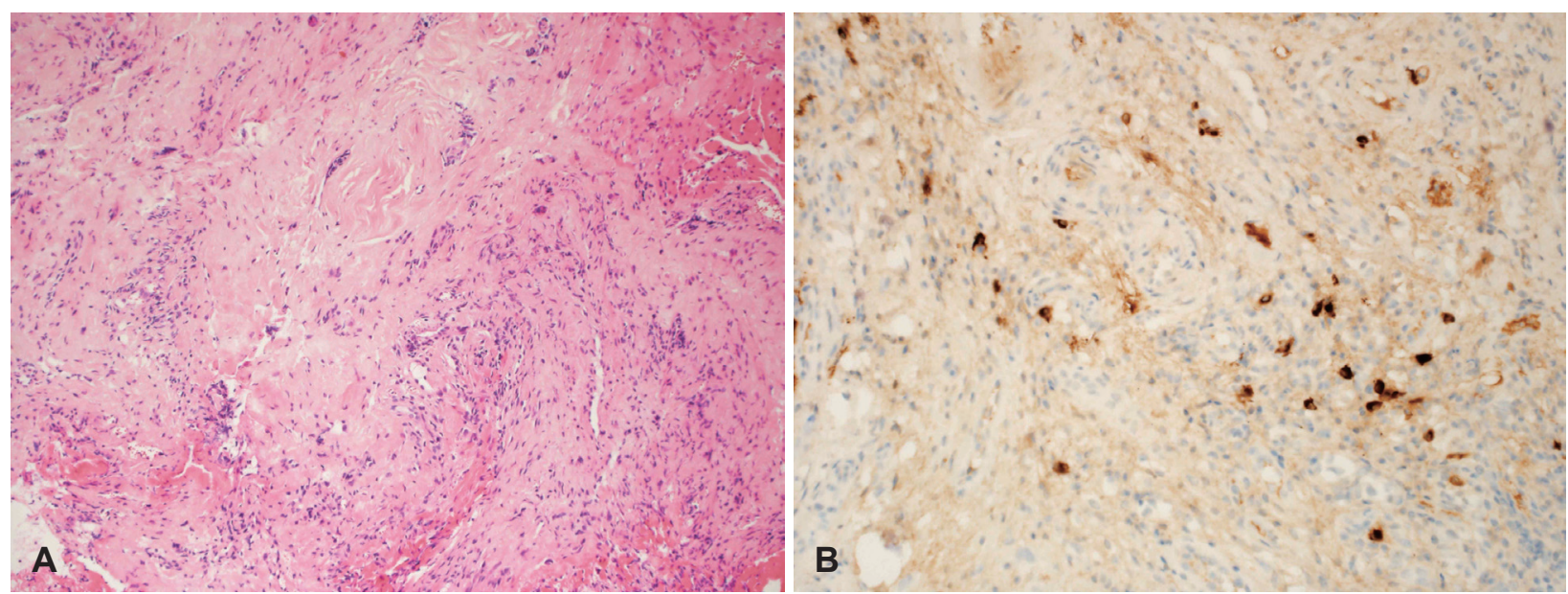

Fig. 4. Immunohistochemical staining shows diffuse and dense sclerosis (H\&E, ×100) (A). Immunoglobulin G4 (IgG4)-positive plasma cells, measureing up to 20/HPF $(\operatorname{lgG} 4, \times 400)(B)$.

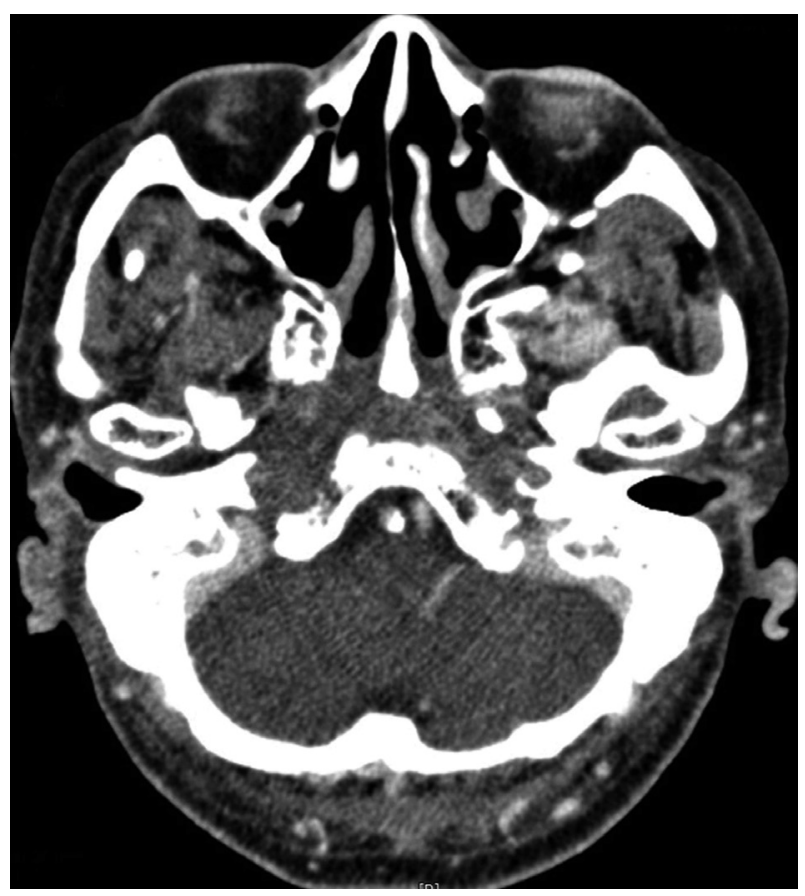

Fig. 5. Enhancing mass and surrounding bony erosion at right nasopharynx was decreased at axial CT scan (1 month after treatment).

도 우측 인두강 내 연조직 종물의 감소 소견을 보였다(Fig. 5). 이후 스테로이드 용량을 감량(prednisolone $0.5 \mathrm{mg} / \mathrm{kg}$ )하여 지속적으로 사용하였으나, 2개월 후 측두부 통증이 악화되어 시행한 단층촬영상 양측 비인두후벽과 인접한 측두골 부위 에 조영 증가된 연조직 종물의 크기가 증가하여 고용량 스테 로이드(prednisone $1 \mathrm{mg} / \mathrm{kg}$ ) 치료를 다시 시작하였다. 30일 간 고용량 스테로이드 치료 후 증상이 다소 호전되어 스테로 이드 용량을 감량(prednisolone $0.4 \mathrm{mg} / \mathrm{kg}$ )하여, 1 개월간 유 지하며 추적 관찰 중이다.

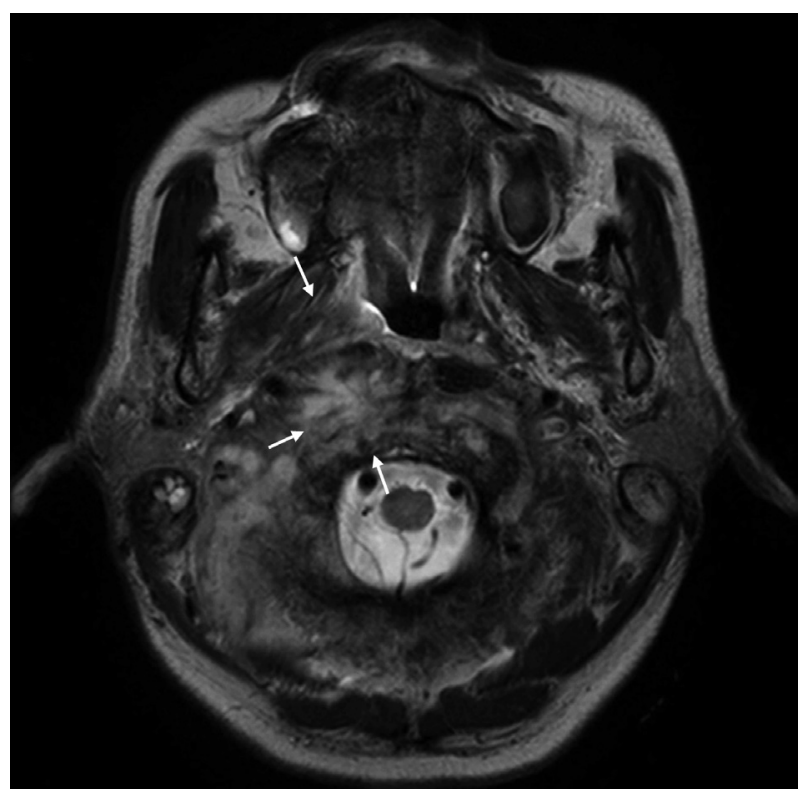

Fig. 6. T2-weighted turbo spin echo image showing enhancing mass at right nasopharynx and prevertebral muscle (arrows).

\section{증 례 2}

60세 남자 환자가 내원 한 달 전부터 시작된 간헐적인 두통, 구음장애 및 3일 전부터 시작된 발열 및 좌측의 안검하수 (ptosis)와 눈 돌출을 주소로 내원하였다. 자기공명영상에서 우측 비인두 및 우측 부인두 공간에 조영이 증강된 종물이 관 찰되었으며, 좌측 후두골 주변에서 연조직 주변의 골 괴사가 동반된 미란성 병변이 관찰되었다(Fig. 6). 양전자컴퓨터단층 촬영에서 좌측 우측 비인두를 중심으로 안구의 뒤쪽과 해면 정맥굴(cavernous sinus), 좌측 측두부와 기저부까지 대사항 진을 보이는 병변이 관찰되었다(maxSUV=6.2)(Fig. 7). 비인 두 내시경 소견상 특이적인 점막 병변은 관찰되지 않았지만 좌측 비인두의 팽륜이 관찰되었다. 이에 비인두암 의심하에 


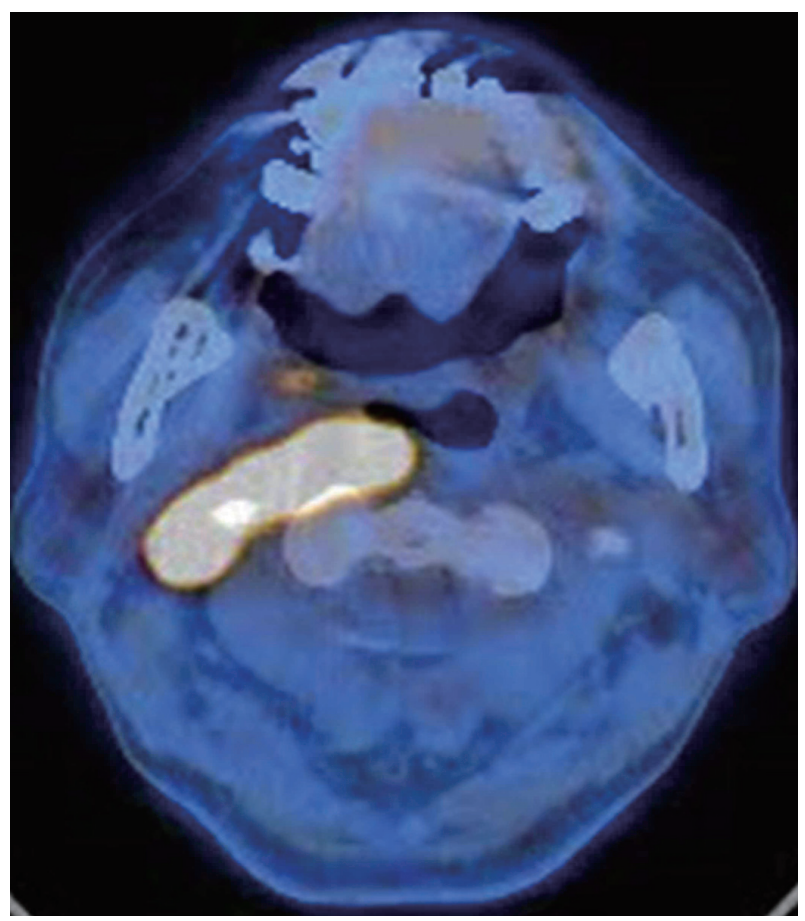

Fig. 7. 18F-fludeoxyglucose positron emission tomography/computed tomography showing hypermetabolic mass at right (maxSUV=6.2)

펀치 생검을 시행하였다. 면역조직화학검사상 형질세포 내의 $\mathrm{CD} 38, \mathrm{CD} 138, \mathrm{Mum}-1, \mathrm{IgG}$ 및 $\mathrm{IgG} 4$ 염색에서 양성 소견을 보여 IgG4 연관 경화성 질환으로 진단하였다. 혈액검사상 백 혈구; $13.6 \times 10^{3} / \mathrm{mm}^{3}$, 적혈구 침강 속도는 $28 \mathrm{~mm} / \mathrm{hr}, \mathrm{C}$ 반응 성 단백질은 $1.37 \mathrm{mg} / \mathrm{dL}$ 로 증가된 소견을 보였으며, $\mathrm{IgG}$ 는 $1510 \mathrm{mg} / \mathrm{dL}$ 로 측정되었다. 2주간의 고용량 스테로이드 치료 (prednisolone $1 \mathrm{mg} / \mathrm{kg}$ ) 후 두통 및 안검하수, 눈 돌출 증상 이 호전되어 스테로이드를 감량(prednisolone $0.8 \mathrm{mg} / \mathrm{kg}$ )하여 4 개월간 지속적으로 사용하였다. 4 개월 후 촬영한 자기공명 촬영상 우측 비인두 및 우측 인두곁 공간의 종물 크기가 감 소하였으나 이전에 관찰되지 않던 주변 근육으로의 침범이 관찰되어 지속적으로 스테로이드를 사용(prednisolone 0.4 $\mathrm{mg} / \mathrm{kg}$ )하며 경과 관찰하였다. 9 개월 뒤 촬영한 경부 자기공 명영상 및 전자방출단층촬영에서 비인두 및 두개저의 섭취 율이 감소하였고, 두통이 호전되어 스테로이드 중단 후 현재 추적 관찰 중이다.

\section{고 찰}

$\mathrm{IgG} 4$ 연관 경화성 질환의 개념은 자가면역 췌장염에 대한 연구에서 발전하였다. 2001년 Hamano 등른 자가면역 췌장 염을 않는 환자들에게서 혈청 내 고농도의 $\mathrm{IgG} 4$ 가 관찰되고 췌장의 면역조직화학검사상 광범위한 $\mathrm{IgG} 4$ 양성의 형질세포
들이 관찰된다고 발표하였다. 그 후로 경화성 담관염, 간 염증 성 위종양(heptic inflammatory pseudotumor), 후복막 섬유 증식증(retroperitoneal fibrosis), 폐 염증성 위종양(lung inflammatory pseudo tumor) 등의 췌장 이외의 섬유 경화성 병 변에서 광범위한 $\mathrm{IgG} 4$ 양성의 형질세포들의 침윤을 특징으 로 하는 사례들이 보고되어, ${ }^{3-5)}$ 현재는 자가면역성 췌장염과 관계없이 $\mathrm{IgG} 4$ 연관 경화성 질환은 여러 장기에 영향을 미칠 수 있다고 받아들이고 있다. 두경부에서는, 만성 경화성 침샘 염(Küttner tumor), 경화성 눈물샘염, 림프구성 형질구성 뇌 하수체염(lymphoplasma cytic hypophysitis) 등의 질환들 이 조직병리학적, 면역조직화학적으로 $\mathrm{IgG} 4$ 연관 경화성 질 환과 같은 특징을 보이고 있기 때문에 $\mathrm{IgG} 4$ 연관 경화성 질 환의 한 종류로 분류되고 있다. ${ }^{6-8)}$ 경화성 눈물샘염의 사례에 서 다수의 IgG4 양성을 보이는 형질세포가 비인두 점막에서 보고된 바 있지만,9) 비인두 부위에서 $\mathrm{IgG} 4$ 연관 경화성 질환 이 보고된 바는 현재까지 없다. 비인두 부위 병변은 신체검사 상 발견하기 어려우며, 초기에는 특징적 증상이 없어 의심하기 어려울 것으로 사료된다. 본 증례에서도 신체검사 및 방사선 소견상 비인두암 의심하에 조직검사를 시행하였으며, 예측한 결과가 나오지 않아 펀치 생검을 반복하여 시행하였다.

조직학적으로 $\mathrm{IgG} 4$ 연관 경화성 질환은 림프형질구성 염증 (lymphoplasmatic inflammation)을 보이며 나선형(storiform) 의 섬유화 및 폐쇄성 소정맥염(obliterative venulitis)의 특징 을 보인다. 림프형질구성 염증은 특징적으로 림프구가 조밀하 게 응집하여 배중심(germinal center)을 형성하며, 림프구성 소정맥염이 흔하게 관찰되지만 육아조직이 발견되지는 않는 다. ${ }^{10)}$ 최근에는 면역조직화학검사상 $\mathrm{IgG} 4$ 가 풍부한 림프구 성 형질구성 침윤이 중요한 특징으로 인식되고 있다. 특히 고 배율 시야상 IgG4 양성인 형질세포의 평균 개수가 진단에 있 어서 중요하다고 보고되고 있으며, IgG4 양성 형질세포의 수 가 고배율에서 10 20개 이상인 경우를 기준으로 하나 명확 한 기준은 아직 논쟁 중이다. 이는 IgG4 형질세포가 영향을 미치는 조직의 종류에 따라 다양하고, 단순 조직검사로 얻었 는지 수술로 얻은 조직인지에 따라 달라질 수 있기 때문으로 생각되고 있다. ${ }^{11)}$

일본에서 제시된 $\mathrm{IgG} 4$ 연관 경화성 질환 진단기준에 따르 면 첫째, 하나 혹은 여러 장기에 광범위한 혹은 국소적인 종 창 혹은 종물이 임상적으로 관찰되며 둘째, 혈청 내 $\mathrm{IgG} 4$ 농 도가 증가해 있으며 $(\geq 135 \mathrm{mg} / \mathrm{dL})$ 셋째, 뚜렷한 림프구와 형 질세포의 침윤과 섬유화가 관찰되고 $\mathrm{IgG} 4+$ 와 $\mathrm{IgG}+$ 의 비가 $40 \%$ 이상이거나 $\mathrm{IgG} 4+$ plasma cells/HPF가 10 이상이어야 한다. ${ }^{11)}$ 세 가지 조건을 모두 충족시킬 경우 확진(definite)할 수 있으며, 첫 번째와 세 번째 조건을 만족시킬 때 추정(prob- 
able), 첫 번째와 두 번째 조건을 만족시킬 때 의심(possible) 할 수 있다고 하였다. 본 두 개의 증례에서는 첫 번째와 세 번 째 조건을 만족시키므로 $\mathrm{IgG} 4$ 연관 경화성 질환을 추정 진 단할 수 있다.

$\mathrm{IgG} 4$ 연관 경화성 질환의 치료는 당질코르티코이드(glucocorticoid)가 주된 치료법으로 알려지고 있다. 당질코르티 코이드는 임상적인 특징을 개선시킬 뿐만 아니라 혈청 내 $\mathrm{IgG} 4$ 수치와 조직 내 $\mathrm{IgG} 4$ 양성 형질세포의 수를 감소시킨 다고 보고되고 있다. ${ }^{7)}$ 본 증례에서도 고용량 스테로이드 치료 (prednisolone $1 \mathrm{mg} / \mathrm{kg}$ )를 시행하고 증상이 호전되어 스테로 이드를 감량(prednisolone $0.4 \mathrm{mg} / \mathrm{kg}$ )하여, 복용 후 스테로이 드 사용을 중단하였다.

일반적으로 $\mathrm{IgG} 4$ 연관 경화성 질환의 예후는 양호한 것으 로 보고되고 있으나 만성 염증과 섬유화로 인해 국소적으로 파괴적인 특징을 가질 수 있기 때문에 빠른 당질코르티코이 드 치료가 필요하다. 당질코르티코이드 치료를 중단하고 재발 되는 경우도 보고되고 있으며, 차선책으로 리툭시맙(rituximab) 을 사용했을 경우 효과가 있다고 보고된 바 있다. ${ }^{12)}$

본 증례에서도 당질코르티코이드 감량 후 병변이 진행하 는 것을 관찰할 수 있어 충분히 오랜 기간 동안 당질코르티 코이드 치료가 필요한 것으로 사료되며 치료 기간에 대한 연 구가 필요할 것으로 사료된다.

드물지만 $\mathrm{IgG} 4$ 연관 경화성 질환이 악성종양과 관계있을 수 있다는 연구 또한 보고된 바 있다. 이전에 $\mathrm{IgG} 4$ 연관 눈물 샘염으로 진단받은 환자에서 림프종이 발생한 3예를 보고하 면서 $\mathrm{IgG} 4$ 연관 경화성 질환이 만성적인 염증 자극에 의해 림 프종을 유발할 수 있다고 보고된 바 있다. ${ }^{13)}$ 점액상피암종(sclerosing mucoepidermoid carcinoma), 타액도관암(salivary duct carcinoma), 갑상선유두암(papillary thyroid carcinoma) 과 같은 상피성 악성 종양도 그 가능성이 높지는 않지만, IgG4 연관 경화성 질환과 연관이 있을 것으로 제시된 바 있다. ${ }^{14,15)}$

결론적으로 $\mathrm{IgG} 4$ 연관 경화성 질환은 $\mathrm{IgG} 4$ 양성인 형질세 포를 특징으로 하는 질환으로, 두경부에서는 주로 만성 경화 성 침샘염(Küttner tumor), 경화성 눈물샘염으로 발생하지만, 본 증례와 같이 비인두에서 발생할 수 있다. 비인두에서 발생 한 경우 신체검사상 발견되기 어려우며 방사선 소견상 비인 두암과 유사한 양상을 보이기 때문에 비인두 부위 종창과 함 께 방사선 소견상 점막하 조직의 미만성 조영증가 병변이 관
찰되는 경우, 드물지만 $\mathrm{IgG} 4$ 연관 경화성 질환의 가능성을 고 려해야 할 것으로 사료된다.

\section{REFERENCES}

1) Kamisawa T, Okamoto A. IgG4-related sclerosing disease. World J Gastroenterol 2008;14(25):3948-55.

2) Hamano H, Kawa S, Horiuchi A, Unno H, Furuya N, Akamatsu T, et al. High serum IgG4 concentrations in patients with sclerosing pancreatitis. N Engl J Med 2001;344(10):732-8.

3) Zen Y, Harada K, Sasaki M, Sato Y, Tsuneyama K, Haratake J, et al. IgG4-related sclerosing cholangitis with and without hepatic inflammatory pseudotumor, and sclerosing pancreatitis-associated sclerosing cholangitis: do they belong to a spectrum of sclerosing pancreatitis? Am J Surg Pathol 2004;28(9):1193-203.

4) Hamano H, Kawa S, Ochi Y, Unno H, Shiba N, Wajiki M, et al. Hydronephrosis associated with retroperitoneal fibrosis and sclerosing pancreatitis. Lancet 2002;359(9315):1403-4.

5) Zen Y, Kitagawa S, Minato H, Kurumaya H, Katayanagi K, Masuda $\mathrm{S}$, et al. IgG4-positive plasma cells in inflammatory pseudotumor (plasma cell granuloma) of the lung. Hum Pathol 2005;36(7):710-7.

6) Lee KK, Cho HP, Lee YM, Park JH. A case of immunoglobulin G4-related sialadenitis and dacryoadenitis. Korean J OtorhinolaryngolHead Neck Surg 2013;56(7):444-7.

7) Kitagawa S, Zen Y, Harada K, Sasaki M, Sato Y, Minato H, et al. Abundant IgG4-positive plasma cell infiltration characterizes chronic sclerosing sialadenitis (Küttner's tumor). Am J Surg Pathol 2005;29 (6):783-91.

8) Wong S, Lam WY, Wong WK, Lee KC. Hypophysitis presented as inflammatory pseudotumor in immunoglobulin G4-related systemic disease. Hum Pathol 2007;38(11):1720-3.

9) Cheuk W, Yuen HK, Chan JK. Chronic sclerosing dacryoadenitis: part of the spectrum of IgG4-related Sclerosing disease? Am J Surg Pathol 2007;31(4):643-5.

10) Deshpande V, Zen Y, Chan JK, Yi EE, Sato Y, Yoshino T, et al. Consensus statement on the pathology of IgG4-related disease. Mod Pathol 2012;25(9):1181-92.

11) Umehara H, Okazaki K, Masaki Y, Kawano M, Yamamoto M, Saeki $\mathrm{T}$, et al. Comprehensive diagnostic criteria for IgG4-related disease (IgG4-RD), 2011. Mod Rheumatol 2012;22(1):21-30.

12) Khosroshahi A, Bloch DB, Deshpande V, Stone JH. Rituximab therapy leads to rapid decline of serum IgG4 levels and prompt clinical improvement in IgG4-related systemic disease. Arthritis Rheum 2010;62(6):1755-62.

13) Cheuk W, Yuen HK, Chan AC, Shih LY, Kuo TT, Ma MW, et al. Ocular adnexal lymphoma associated with IgG4+ chronic sclerosing dacryoadenitis: a previously undescribed complication of IgG4related sclerosing disease. Am J Surg Pathol 2008;32(8):1159-67.

14) Gill J, Angelo N, Yeong ML, McIvor N. Salivary duct carcinoma arising in IgG4-related autoimmune disease of the parotid gland. Hum Pathol 2009;40(6):881-6.

15) Tian W, Yakirevich E, Matoso A, Gnepp DR. IgG4(+) plasma cells in sclerosing variant of mucoepidermoid carcinoma. Am J Surg Pathol 2012;36(7):973-9. 